\title{
An Analysis on Forms and Contexts of the Word 'When' in Japanese Language
}

\author{
Hartati \\ Japanese Literature Department \\ Jenderal Soedirman University \\ Purwokerto, Indonesia \\ tatitasen@gmail.com
}

\author{
Anggita Stovia \\ Japanese Literature Department \\ Jenderal Soedirman University \\ Purwokerto, Indonesia \\ anggita.stovia@gmail.com
}

\begin{abstract}
The purpose of this research is to figure out the forms of the word "when" and describe its contexts in Japanese language. This descriptive-qualitative research employed a writing technique while the data are analyzed using a distributional method. The data consist of sentences containing the word 'when' context, word, when, Japanese language available in Minna no Nihongo textbook. The results of analysis show that there are various forms of the word 'when', such as the word toki, sai, tokoro, and others in Japanese Language based on contexts used in sentences.
\end{abstract}

\section{Keywords-form, context, word, when, Japanese language}

\section{INTRODUCTION}

Japanese language is one foreign languages which has various letter forms, covering hiragana, katakana, and kanji. One of difficulties faced by the Japanese language students at university in learning Japanese language is related to those letter forms in addition to the Japanese grammatical patterns. Grammar or sentence patterns consist of words when combined may form a sentence element, and then form a sentence. Not only on the grammatical structure which requires to be paid more attention by the language users not only to deliver the intended meaning to the hearers but also the meaning of each word contained in a sentence spoken by the speaker. The linguistic study which discusses meaning is called semantics. Semantics is a branch of linguistics which has an important role in language since the language basically used in communication is to convey those meanings. A linguistic unit also has a word meaning which relates each other called a meaning relation. One realization of meaning relation is synonym.

Synonym is a semantic relationship stating that there is a meaning similarity between one utterance and the others (Chaer, 2014:p. 297). There are many synonyms in Japanese language as it is considered as one language which is rich with grammatical structures and vocabularies. Many synonyms in Japanese language make the Japanese students feel that it is not easy to learn the language. Most Japanese language learners only know the meaning from the related vocabularies when translated to Indonesian language. Japanese language learners frequently do not understand that a certain word has synonyms when translated to Indonesian language and different meanings when used in different sentences. The word 'when' is the one which adequaltely has various synonyms in Japanese language that eventually result in students' confussion in using those words. There are some similar researches conducted on the word toki and others included in the group of keishiki meishi in Japanese language. (https://repository.kulib.kyotou.ac.jp/dspace/bitstream/2433/8 7869/1/kgn00025_001.pdf). However, a research employing a textbook as the data source, such as Minna no Nihongo has never been done before. Thus, the researchers consider that it is greatly necessary to conduct a research entitled "An Analysis on Forms and Contexts of the word 'When' in Japanese Language".

\section{THEORETICAL BASES}

\section{A. Semantics}

Sutedi (2011: p. 127) explains that semantics or in Japanse language known as imiron is one linguistic branch discussing meaning. Semantics has an important role since the language used for communication is to convey meaning. For instance, when someone expresses his ideas or thoughts, the hearers directly understand the meaning of the delivered utterances. The object of semantic study includes the word meaning (gonoimi), meaning relation between one word and the others (gonoimikankei), phrase meaning (kunoimi), and sentence meaning (bun no imi).

Chaer (2014:297) explains that in linguistic unit, there are interrelated word meaning, in this case, in the forms of words, phrases, and sentences. This relationship is called meaning relation. The realization available in meaning relation incluses homonymy (meaning relation between words written or spoken in the same ways, yet the meaning is different), synonym (between words, phrases, or sentences with the same or similar meaning), antonym (between words with opposite meaning), polysemy ( a word with more than one meaning), hiponymy (a form of utterance which meaning includes the others), ambiguity (multiple meanings resulted from different grammatical interpretation), and redundancy (the use of segmental elements in the hyperbolic utterances).

\section{B. Synonyms}

Sutedi (2011: p. 145) states that synonym in Japanse language is called ruigigo. Ruigigo (synonym) is one object of semantic study. Synonym is several words with a closely 
similar meaning. Krida laksana (in Aminuddin, 2008: p. 115) also defines that synonym is a linguistic form with a similar or the same meaning with the other forms as the similarity is applicable for words, a group of words or sentences, although only words are considered synonym.

Momiyama (in Sutedi, 2011: p. 145) recommends ways to identify a synonym, as follows:

- Chokkanteki (linguistic intuitive) for native speakers based on their life experiences. When listening to a word, the native speakers may directly feel that whether the word has synonyms or not.

- Some words when translated to the other foreign language may have the same meaning, such as the word oriru, kudaru, sagaru, and furu that in Indonesian language is equalized with the word turun.

- May occupy the same position in a sentence with a small meaning difference.

- In asserting a meaning, both may be use at the same time or at once. For instance, the word hikaru (光る) and kagayaku (輝 $<$ ) which both mean ,bersinar [shining], may be used at the same time, such as in Hoshigahikari-kagayaiteiru (星が光り輝いている) „Bintang bersinar cemerlange [The star shines brightly].

\section{Class in Japanese Language Grammatical Patterns}

In Japanese language, the word class is called hinshi.

“品詞は文中での統語的機能にもとづいて語を分類し たものとされているが、統語的機能については前節で 規定しておいた。すなわち、統語的構造のどの位置に くるかということで、語を分類すればよい”。（小泉， 1993:164)

Hinshiwabunchūdenotōgo-

tekikinōnimotodzuitegoobunruishita monotosareteiruga, tōgotekikinōnitsuitewazensetsudekitei shiteoita. Sunawachi, tōgotekikōzōno donoichinikuruka to iukoto de,-go o bunruisurebayoi (Koizumi, 1993: p. 164)

The word class is defined as the classification of words based on the syntactic structure in the previously explained sentences. In other words, the position of this syntactic structure is adequate to classify those wordse (Koizumi, 1993:164).

Hinshi in Japanese language has ten word classes which eight of those are included into jiritsugo and the other two classes are classified into fuzokugo (Sudjianto, 2004: p. 147). Doushi (Verb), I-keiyoushi (adjective-i), Na-keiyoushi (adjective-na), Meishi (Noun), Rentaishi (Pronoun), Fukushi (Adverb), Kandoushi (interjection), Setsuzokushi (Conjuction), Jodoushi (Auxiliary), Joshi (Particle).

\section{RESEARCH TYPE}

The type of this research is classified into a descriptivequalitative research which describes forms and contexts of the word 'when' in Japanese language. The data were collected by using a writing technique. A writing technique is a data collection technique by writing the results of the observed data (Kesuma, 2007: p. 45). The resulted data then were analyzed by a distributional method. Sudaryanto (in Kesuma, 2007: p. 54) states that distributional method aims at analyzing the data containing linguistic phenomena available in the related language.

\section{RESULT AND DISCUSSION}

In this chapter, the researchers discuss the use of the word 'when' in Japanese language sentences available in Minna no Nihongo textbook. Most universities in Indonesia teaching Japanese language use that textbook as one major reference for teaching accompanied by the other references. The researchers conduct the analysis based on the use forms, meaning and whether or not the word "when" in Japanese language may replace each other within a sentence.

\section{- Data (1)}

国へ帰つたとき、かばんを買いました。

Kuni he kaetta toki, kaban wokaimashita

'Ketika pulang ke negara, saya membeli tas'

[When going back to my country, I bought a bag]

(Minna no Nihonggo shokyu I:192)

Based on data (1), the word toki follows the futsuukei verbs with past time signal (kakokei) that is kaetta 'sudah pulang' [having been back home]. Futsuukei is a basic form which may be equalized with the verb forms contained in the dictionary possessing the characteristics of word ending sound of $\sim u, \sim t s u, \sim r u, \sim b u, \sim n u, \sim m u, \sim k u, \sim g u, \sim s u, \sim i r u, \sim e r u$, and verb suru, kuru ${ }^{\text {ee }}$. The verbs with those ending sounds are presented in table 1:

Fig. 1. The example of Futsuukei verbs

\begin{tabular}{|c|c|c|}
\hline Verb Group & Verb Futsuukei & Meaning \\
\hline \multirow{6}{*}{ I } & $\begin{array}{c}\text { あう } \\
A u\end{array}$ & Bertemu [ to meet] \\
\hline & $\begin{array}{l}\text { かつ } \\
\text { Katsu }\end{array}$ & Menang [to win] \\
\hline & $\begin{array}{l}\text { はいる } \\
\text { Hairu }\end{array}$ & Masuk [to enter] \\
\hline & $\begin{array}{l}\text { 遊ぶ } \\
\text { Asobu }\end{array}$ & Bermain [to play] \\
\hline & $\begin{array}{l}\text { 死ぬ } \\
\text { Shinu }\end{array}$ & Mati/meninggal [to die] \\
\hline & $\begin{array}{l}\text { 飲む } \\
N o m u\end{array}$ & Minum [to drink] \\
\hline
\end{tabular}




\begin{tabular}{|l|c|l|}
\hline \multirow{4}{*}{} & 書く & Menulis [to write] \\
& Kaku & \\
\cline { 2 - 3 } & 泳ぐ & Berenang [to swim] \\
& Oyogu & \\
\cline { 2 - 3 } & おす & Mendorong [to push] \\
& Osu & \\
\hline \multirow{4}{*}{ II } & おきる & Bangun [to wake] \\
& Okiru & \\
\cline { 2 - 3 } & ねる & Tidur [to sleep] \\
& Neru & \\
\hline
\end{tabular}

\begin{tabular}{|c|c|l|}
\hline \multirow{3}{*}{ III } & 来る & Datang [to come] \\
\cline { 2 - 3 } & Kuru & \\
\cline { 2 - 3 } & する & Melakukan [to do] \\
\hline
\end{tabular}

a. (http://jakanaka8840.blogspot.co.id)

Besides, in Japanese language, the futsuukei verbs may experience form changes based on time signal (a time signal word, such as contained in the verb かえる kaeru 'pulang' [going back home] and if changed in past time, it may experience a changing process as presented in Diagram. 2:

(1)

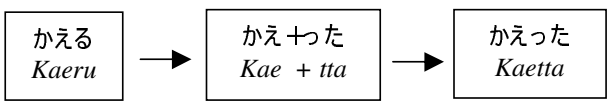

Diagram. 2. The changing Process of Futsuukei verbs

Futsuukei verbs with past time (ta-kei) have the characteristics marked by the presence of the form $\sim t a$ and $\sim$ teiru/ teru with the progressive time signal (genzai-kei) at the end of verbs. The changing pattern on each verb has its own criteria based on the following word ending letter. The futsuukei changing patterns on each verb are presented in table 2:

Fig. 2. Futsuukei verb changing patterns

\begin{tabular}{|c|c|c|c|}
\hline $\begin{array}{l}\text { Verb } \\
\text { Group }\end{array}$ & $\begin{array}{c}\text { Verb ending 普 } \\
\text { 通形 } \\
\text { (Futsuukei) }\end{array}$ & $\begin{array}{c}\text { Past/ } \\
\text { 夕形 } \\
(\text { Takei) } \\
\sim \text { Ta }\end{array}$ & $\begin{array}{c}\text { Progressive/ } \\
\text { 現在形 } \\
\text { (Genzaikei) } \\
\sim \text { Teiru/ } \\
\sim \text { Teru }\end{array}$ \\
\hline \multirow{9}{*}{ I } & j(u) & \multirow{3}{*}{ った(tta) } & \multirow{3}{*}{$\begin{array}{c}\text { っている/ } \\
\text { ってる(tteriru/tteru) }\end{array}$} \\
\hline & $\supset(t s u)$ & & \\
\hline & る(ru) & & \\
\hline & ぶ(bu) & \multirow{3}{*}{$\begin{array}{l}\text { んだ } \\
(n d a)\end{array}$} & \multirow{3}{*}{$\begin{array}{c}\text { んでいる/ } \\
\text { んでる } \\
\text { (ndeiru/nderu) }\end{array}$} \\
\hline & ぬ(nu) & & \\
\hline & む $(m u)$ & & \\
\hline & $<(k u)$ & いた(ita) & $\begin{array}{c}\text { いている/ } \\
\text { いてる } \\
\text { (iteiru/iteru) }\end{array}$ \\
\hline & ぐ $(g u)$ & いだ(ida) & $\begin{array}{l}\text { いでいる/ } \\
\text { いでる } \\
\text { (ideiru/ideru) }\end{array}$ \\
\hline & す $(s u)$ & $\begin{array}{l}\text { した } \\
\text { (shita) }\end{array}$ & $\begin{array}{l}\text { している/ } \\
\text { してる } \\
\text { (shiteiru/ }\end{array}$ \\
\hline
\end{tabular}

\begin{tabular}{|c|c|c|c|}
\hline & & & shiteru) \\
\hline \multirow[t]{2}{*}{ II } & いる(iru) & \multirow{2}{*}{$た(t a)$} & ている/てる \\
\hline & える(eru) & & (teiru/teru) \\
\hline \multirow[b]{2}{*}{ III } & $\begin{array}{c}\text { 来る } \\
\text { (kuru) }\end{array}$ & $\begin{array}{l}\text { 来た } \\
\text { (kita) }\end{array}$ & $\begin{array}{c}\text { 来ている/ } \\
\text { 来てる } \\
\text { (kiteiru/kiteru) }\end{array}$ \\
\hline & $\begin{array}{c}\text { する } \\
\text { (suru) }\end{array}$ & $\begin{array}{c}\text { した } \\
\text { (shita) }\end{array}$ & $\begin{array}{c}\text { している/ } \\
\text { してる } \\
\text { (shiteiru/ } \\
\text { shiteru })\end{array}$ \\
\hline
\end{tabular}

Toki contained in the utterance kuni he kaettatoki has the meaning 'ketika sudah pulang ke negara' [after going back home to the country], then followed with the utterance kaban wo kaimashita which means 'saya membeli tas' [I bought a bag]. That utterance is one event taking place after the activity of going back home to the country occurs. Thus, utterance 1 has its meaning after going back home to the country, then (I) bought a bag. Since the word kaetta shows that the activity has been completed. Furthermore, the use toki in utterance 1 directly spoken by the speaker with a formal language as marked with the use of verb in the form of masu contained in the word kaimashita at the end of the sentence.

- Data (2)

カーテンを変えたら、部屋が明るくなった。

Kaatenwo kaetara, heya ga akarukunatta

'ketika gorden diganti, ruangan menjadi terang'

[When the curtain changed, the room got brighter]

(Minna no Nihongo Chuukyu I: p. 51)

Data (2) shows that the second sentence is the result or impact of the undertaken first activity that the room got brighter when the curtain changed. The word toki follows the futsuukei verb in past time (kakokei) that kaeta replace that combined with tara (conditional form, if/when), then is followed by a verb in the form of ta (lampau) contained in the phrase akaruku natta (menjadi terang [got brighter]). The meaning contained in sentence kaaten wo kaetara, heya ga akarukunatta is that the room got brighter since there is an activity of changing the curtain. The expression -tara contained in data (2) shows an activity conducted toward the curtain in a room which newly results in a brighter room.

The discussion results of both data show that the word "when" in Japanese language has various synonyms, including the word $\sim$ toki, $\sim$ tara, sai, $\sim$ tokoro and more. Those word forms are gramatically based on similar use and meaning in meeting the context of sentences in Japanese language. Meanwhile, the examples of the other researches with different studies show that the words classified into keishiki mesh $i$ when practically analyzed have different meanings as the word toki may not be separated from the past time aspects, and may be used in all situational aspects. Meanwhile, the word tara may be freely used in non-gramatical 
forms.(https://repository.kulib.kyotou.ac.jp/dspace/bitstream/2 433/87869/1/kgn00025_001.pdf).

\section{CONCLUSION}

A. The use forms of the word 'when'

- Toki

Following the word class in the use forms of noun, pronoun, adjective- $n a$, adjective $-i$ and verb futsuukei 'regular form'. The special for noun + toki is used to give particle no as conjuction. Besides, toki is flexible since toki may be used in both formal and non formal language form either in spoken or written.

$$
\text { - } \sim \operatorname{tara}
$$

The word form of verb $+\sim$ tara, which is then followed by a verb or adjective in the past form $\sim t a$, has a meaning that a sentence after the form $\sim$ tara is "resulted" from the sentence action following the form $\sim$ tara. Besides, this pattern has also a meaning that a sentence after the form tara is a sentence to indicate "finding" something new.

\section{B. Meaning}

Toki and tara are positioned as meishi (noun), that is, keishikimeishi. Keishikimeishi is a word class formally explaining its function without possessing the essencial or real meaning as noun that it can be concluded that toki and tara do not have a clear meaning if not attaching to the other word. The word toki and tara when translated to Indonesian language may have the same meaning including waktu [time], ketika [when], saat [while], yet the function of both word forms is slightly different. Toki and tara has the function to explain time when an activity, event, and condition take place based on the sentence context. Besides, tara has an addition meaning as jokenkei, or conditional.

\section{Toki and $\sim$ tara Position}

Based on the result of analysis conducted by the authors, toki and tara may replace each other when both are related to time, activity, event, and condition, yet should be adjusted to the context of sentence and hearer. Toki may not replace $\sim$ tara when followed by pronoun kono since resulting in different meaning, Meanwhile, tara may not be replaced by toki when followed by adjective, a sentence referring to itself.

\section{Reference}

Chaer, A. (2014). Linguistik umum edisi revisi Jakarta: Rineka Cipta.

Kesuma. (2007). Pengantar (metode) penelitian bahasa. Yogyakarta: Carasvatibooks.

Koizumi, T. (1993). Nihongo kyoushino tameno gengogaku nyuumon. Second edition. Tokyo: Taishukan.

Sudjianto, D. A. (2004). Pengantar lingistik bahasa Jepang. Jakarta: Kesaint Blanc.
Sutedi, D. (2011). Dasar-dasar linguistik bahasa Jepang. Bandung: Humaniora. 